\title{
Network Society and Democracy: How ICT Mediated Communication and Virtual Socialization Affects Political Participation
}

Original scientific paper _ UDK 004.738:316.772.5 _ 323.21 _ Received on 3 November 2015

\section{Pero Maldini}

Department of Communication Science, University of Dubrovnik,

Ulica branitelja Dubrovnika 29, Dubrovnik, Croatia. Email: pero.maldini@unidu.hr

\section{Abstract}

The article deals with the issue of political participation in the network society. It examines how new forms of public communication enabled by ICT mediated communication (especially new media), as well as virtual socialization and the resulting new social structures (especially social networks), affect political participation, particularly citizens' influence on the government and the political decision-making processes. An analysis of these relationships shows that the changes brought by ICT, in both the social structure and the area of public communication equally, and the expansion of space of political freedom and political communication, do not increase political participation by themselves. It is determined primarily by technological requirements, and then by sociostructural and sociocultural factors, as endogenous properties of certain societies that substantially determine their overall social and political dynamics. In that sense, the level of development of the virtual sphere, the numbers and diversity of social networks and new media, cannot by themselves be considered to be independent variables, nor can they be considered outside of the specific social context. This is particularly noticeable in transitional societies in which specific (undeveloped) sociostructural and sociocultural factors are the key obstacle to the development of political participation, and hence democracy.

Keywords: political participation, democracy, network society, ICT, social networks, new media, public sphere 


\section{Introduction}

In the last two decades, information and communication technologies (ICT) have transformed the structure of modern societies and the way they function. The Internet, as the network of all networks, has overcome the, until recently, insurmountable limitations on time, place, amount, and type of information able to be exchanged. Unlike traditional media (including the electronic ones) which functioned as one-way communication channels, the Internet enables real-time interactivity. This marked a technological and communication revolution, greater and more important than the one marked by Guttenberg's invention almost six centuries ago (McLuhan, 1962). The unlimited sphere of free information and the forms of its exchange has enlarged the sphere of individual freedoms and of the possibilities for public political action by individual and social groups. ${ }^{1}$ New media have enabled the transformation of the reader, listener, and viewer - in a word, the passive consumer of informative content - to an active producer of information. From the political aspect, citizens gained an instrument that can promote them from passive receivers of political decisions to versatile and active political participants. Consequently, new technologies have also started changes in the social structure and the functioning of modern societies.

However, society created upon these new technological foundations still did not fulfill the visions of its visionaries: in the sense of the ultimate victory of democracy as the world's order (Huntington, 1991; O’Donnell, Schmitter, 1986; Fukuyama, 1989), ${ }^{2}$ in the sense of the world as a global village (McLuhan, 1968; Robertson, 1992, 1995), or in the sense of the network society as a socially, spatially, and temporally diversified global community of interconnected social networks (Castells, 1996, 2000; van Dijk, 2006). Although contemporary societies are indeed being transformed in those directions, the development is by no means even or linear.

Indeed, in parallel with the great ICT-caused changes, there has been a decline of democracy in both developed democratic societies, the so-called post-democracy phenomenon

1 Variety of open sources, which are a new and huge benefit brought by the Internet, offer alternative ways of getting information, which is very important in achieving insights into what is going on. Blogs, chat rooms, discussion forums, various kinds of social groups (political, cultural, professional, artistic, sports, leisure, etc.) create virtual communities, which represent an extension of civil society (Davis, 2005; Norris, 2001).

2 These expectations are perhaps best described by F. Fukuyama's claim of the "end of history" with regard to the fall of communism, since the processes of democratic transition had begun in nearly all former autocratic societies, and the realization of democracy as a universally accepted global order seemed almost certain (Fukuyama, 1989). 
(Crouch, 2004; Wolin, 2008; Ranciere, 2008) and post-authoritarian transitional societies, nonconsolidated; illiberal and defective democracies (Merkel, 2004; Beyme 1996; Offe, 1997; Maldini, 2013a). Thereat, the question of political participation and citizens' influence on political decision-making imposed itself as one of the central questions for the vitality and development of democracy. Political participation became an important indicator of the quality of democracy, and the development of ICT has greatly changed its character and abilities. However, the enormous potential enabled by ICT has turned out to be limited in its scope. The influence of new media and social networks was shown to be insufficient in terms of greater control over political power and citizens' greater influence in the process of political decision-making.

Regarding protests, as the characteristic form of civil activism and/or direct democracy, it is evident that many mass protests are directly incited and directed on social networks. In addition, numerous civil initiatives, whether in single countries or on an international level, have roots in the cyberspace. Indeed, outside of it, they would not be possible. Some of these initiatives directly influenced the government's behavior and actions, whether on the national or the international level. However, the influence of some of the other initiatives had almost no effect; some even introduced retrograde changes (from the perspective of democratic development). ${ }^{3}$ On one hand, we thus have evidently increased political participation, while on the other, we have dubious results in terms of its pro-democratic impact. If political participation is a key characteristic of democratic development, then such an occurrence is paradoxical.

The question arises of whether the new social structures (especially social networks) and the new forms of public communication (especially new media) created by the new ICT also enabled citizens to have a greater influence on the processes of political decision-making. In other words, it is necessary to consider how much did the new horizontal networks of social bonds and the substantial expansion of the public communication sphere influence the increase of citizens' political engagement, i.e. their political participation.

Our assumption is that, despite the huge changes brought by ICT in the social structure as

3 Some of the best known such actions in the recent period are Occupy Wall Street, Facebook and Twitter revolutions in northern Africa and Middle Eastern countries (the so-called Arab Spring) in 2010-2012, the Icelandic Facebook revolution of 2010, Croatian anti-government protests of 2011, Ukrainian EuroMaidan in 2013, the 2014 Umbrella Revolution in Hong Kong, etc. 
well as the public communication sphere, political participation is determined primarily by socio-structural and socio-cultural factors - the endogenous characteristics of individual societies which substantially determine their entire social and political dynamics. In this sense, the objectively widened possibilities of political participation and their potential influence on political decision-making will be stimulated or limited by precisely these endogenous factors, characteristic for each individual society. Therefore, this article aims to analyze the influence of those factors on political participation through ICT-mediated communication and virtual socialization, with a focus on citizens' impact on the political power and the processes of political decision-making.

\section{Democracy and political participation: Sociostructural and sociocultural prerequisites}

The efficiency of a democratic political system is expressed not only in formal political competition through institutions, but also in real, effective democratic practices, which requires inclusive civil participation. ${ }^{4}$ When citizens have the chance to think about key public questions, consider alternative political options, evaluate their wishes and abilities, they participate in shaping the government's policies, while the government and its decisions gain greater legitimacy. Citizens' solidarity based on inclusive participation of all brings more self-respect, greater optimism, less fear, and consequently an increase in political trust and tolerance.

Political participation, as a form of direct and unmediated democracy, does not mean negating the functions of the institutions of representative democracy, since most decisions cannot be made by direct decision-making, but solely through the institutions. Forms of political participation exist in parallel with the representative institutions and the government, overcoming the limitations and expanding the possibilities of representative democracy.

4 Formal (or political) democracy connotes a set of rules, procedures, and institutions that make up the normative-institutional constitution of a democratic order. It is a minimal and indispensable prerequisite, the institutional and political frame that enables the basic functioning of democracy. A substantive democracy, however, also requires wide political participation and effective mechanisms for civic control over political authorities through acceptance and articulation of citizens' opinions, and the implementation and protection of freedom, equality, and civil rights. It requires a democratic process which continuously reproduces itself as a form of regulating the power relations so that it maximizes the abilities of the individuals and their influence on their living conditions - to participate in discussions and influence the decision making process (cf. Kaldor, Vejvoda, 1997, pp. 62-63; Tilly, 1999, pp. 4-9; Dalton, 2006, pp. 35-60; Grugel, 2001, p. 7; Maldini, 2008, pp. 30-36). 
Without such a form of direct civil influence, proper democratic relations are hard to set up, and the possibilities of the government reaching into citizens' rights and freedoms in an authoritarian manner increase.

Participation therefore imposes itself as the essence of the democratic political process. It enables the transformation from subject to citizen, i.e. the transformation from a passive recipient of government decisions to an active subject of political (joint) decision-making. Developed political participation is thus a constitutive element of modern democracies and a prerequisite for democratic control of the government (by limiting and correcting it through the public sphere).

In developed democracies, the level of conventional political participation (voting turnout) has not been particularly high for a long time now, but it is stable and predictable. The level of nonconventional participation (public demands, petitions, political protests) and civil participation (civil associations' and social movements' actions), on the other hand, is far higher and still rising.

However, political participation has at least two key requirements. The first one is a relatively high level of political competence, as a key socio-cultural determinant. ${ }^{5}$ Undeveloped and unstable societies are marked by a low level of political competence, which lets content and political goals be ignored in favor of political structures and processes. Major political and social forces are concentrated around them and all the essential social questions are viewed through them. It is a characteristic of many post-authoritarian societies in transition, which are marked by domination of political structures in all relevant segments of social life. Low political competence, most often as a consequence of authoritarian political and historical legacy and undeveloped civic culture, ${ }^{6}$ is manifested as incomprehension of the democratic political system functioning and as inability to properly articulate political

5 The belief that the individual can have a certain amount of oversight over political structures and the decision-making processes is a key component of democratic political culture. The subjective belief in the ability to act politically represents political competence. It denotes the ability to understand and evaluate political processes and political relations, and the critical attitude of the individual towards them. Citizens' orientation towards the political structures and political processes thus depend on its quality. It is manifested more frequently in individuals with greater education, in members of various volunteer associations (cultural, sport, professional, charity) and those with prior experience of participation (in decision-making within the family, the school, at work, and within other social groups) (Almond, Verba, 2000, pp. 136-138; 160-171).

6 Along with political competence (knowledge about the political system and the awareness of the possibility and the readiness to act politically), the existence of developed political and social trust among citizens, a steady relationship with the political elites, and the affective (not merely instrumental) attachment to the democratic political system (i.e. adherence to democratic values) are also very important. This is precisely why such a form of political culture can safeguard the efficient functioning, durability, and stability of a democracy (cf. Vujčić, 1999, p. 120). 
interests, which results in a low level of citizens' political participation and their rather weak influence on political decision-making.

The second key requirement is a developed civil society as its socio-structural determinant. When it is widely organized and vibrant, and when there is a diversity of forms of political participation, civil society establishes itself as autonomous with regard to government, as a center of power beyond the state. ${ }^{7}$ It becomes a factor which guarantees the separation of state from society and represents a barrier against attempts by the state (political power) to interfere with civil autonomy. In that way, it consistently acts towards the democratization of politics and maintenance of a reliable state.

A wide network of non-governmental civil societies and movements, their horizontal connectedness, and their public action constitutes the public sphere, in which the public opinion is shaped. ${ }^{8}$ The public is a place of articulation and mediation of all social interests. With respect to the government and the state, it acts as their control mechanism and a corrective of their actions, enforcing openness and transparency. Since the government ought to respect and advance the common good and the public interest, it has to be responsible to the public for its actions.

\section{Transformation of public sphere and mass media}

The mass media are key mediators in the process of shaping public opinion. They are the dominant channel for exchanging information and gaining insights into the common

7 Civil society denotes the space between the state and the individual, between the public and the private, between the "lifeworld" and the system (political sphere). It encompasses a variety of social organizations and civil associations that enable civil organization outside and opposed to the state, and the public area where citizens can openly discuss and articulate their interests outside the regular institutions of political representation. In that way, citizens promote their interests, practice the civic values and trust, and force the state to act responsibly. The characteristic postmodern understanding defines civil society as a form of political society based on a dense network of NGOs and groups based on autonomous monitoring of various socio-economic interests, ready to turn away attempts by the state to gain control over those activities. Parts of civil society include elements such as: independent media, religious communities, humanitarian organizations, business lobbies, professional associations, syndicates, universities, and noninstitutionalized movements for various social actions (Habermas, 1991; Zakošek, 1991; Böckenförde, 1991; Inglehart, Welzel, Klingemann, 2003; Maldini, 2002, 2008).

8 A key component of civil society (sometimes used as a synonym) is the public sphere, as a space between the private sphere and the state, a space in which social and political interests are freely expressed and articulated, and public opinion is created. Public opinion, in turn, is the totality of citizens' political expressions as private entities in the form of public discourse. Democracy as a political system lives from the public, since the entire political life of a democratic community takes place in that sphere (Habermas, 1991; Posavec, 2004; Maldini, 2008, pp. 203-216). 
reality by both citizens and political actors. In a developed democracy, free and independent media enable diverse segments of the public to express their opinions and facilitate the process of bringing collectively binding decisions and creating public policies. Free and independent media also enable access to the public for unprivileged social groups, as well as support for the political opposition, ensuring their right to publicly challenge the political government and its policies. In this way, the media support the essential democratic values, and consequently foster democracy as a desirable political system. ${ }^{9}$

All of that, however, is based on the assumption that equates ideal democracy and participative democracy, where politically well-informed citizens have an important role in the political process. But the question is - is participative democracy feasible, and to what extent? - when the contemporary public is too large to engage in public discussions, where citizens could clearly communicate with each other (Graber, 2003, p. 143). Besides, democratic discussion in modern societies is congested by the proliferation of mass media as an instrument of mass entertainment, making the public sphere commercial, and shaping the public opinion under the influence of various kinds of manipulation and control instead of rational criteria, making the public sphere unauthentic (Habermas, 1991). Instead of actual political issues and democratic dialogue, the public sphere is increasingly filled with political-communication technologies, such as mediatization and personalization of politics, the construction of a political spectacle, advertising and media spin. All of that substantially impairs the ability to clearly perceive political actors, pushes their political programs into the background, and shifts public attention from important political questions to ephemeral phenomena. Here, the media act not as mediators of public opinion, but as creators of social and political reality (Edelman, 2003; Meyer, 2003; Crouch, 2004).

On the other hand, contemporary mass media have overcome the communication restrictions of space and time which had existed until recently. New forms of communication and dissemination of information create new and different forms of interaction. Mediated

9 In a democratic regime, the media should satisfy four requirements: a) provide space for discussion between different, often conflicting ideas; b) give voice to the public opinion; c) be the citizens' eyes and ears in the task of supervising the political scene and the government's actions; d) act as a public monitor and alert the general public whenever improper behavior, corruption, or abuse of power in political institutions is noticed (Graber, 2003, p. 143). The essential functions of democratic media are: informing the citizens, educating them (in the sense of interpreting the context of facts), being a platform for public political discourse which facilitates the formation of public opinion, providing publicity to political institutions, and being a channel for advocating political standpoints (McNair, 2003, p. 28). A democratic political community depends on the way it sees itself. That image, for the most part, is communicated by mass media. 
communication is becoming increasingly prevalent compared to direct communication, and global communication networks are increasingly influencing changes in social traditions, reshaping the process of socialization, and changing the character of the public sphere. Contemporary forms of communication and the new media act between the global and local level, directly influencing the everyday life of citizens, as well as changes in social power relations and in the public sphere (Thompson, 1995). All of that lies at the basis of the transformation of traditional sociability and of the creation of a new social structure we call the network society.

\section{Technological and communication determinants of political participation in network society}

The network society denotes a new social structure created by the information revolution, i.e. the development of ICT and the restructuring of industrial capitalism into a global market economy. ${ }^{10}$ In this new environment, productivity and competitiveness depend primarily on knowledge, information, and information-processing technology, while local economies increasingly depend on global trends. This affects changes of the following:

a) character of work and employment (flexibility of work arrangements and working hours);

b) structure of the economy (diversified, deterritorialized, networked companies on a global, decentralized, networked, and deregulated market);

c) social stratification (social polarization based on nontraditional channels of social and economic promotion);

d) forms and channels of communication (Internet as a form of two-way communication, new media, and the basis of cyberspace as a virtual extension of real life).

10 As a concept, the network society emphasizes the form and organization of information processing and exchange. An infrastructure of social and media networks takes care of this. So the network society can be defined as a social formation with an infrastructure of social and media networks enabling its prime mode of organization at all levels (individual, group/organizational and societal). Increasingly, these networks link all units or parts of this formation (individuals, groups and organizations). In Western societies, the individual linked by networks is becoming the basic unit of the network society. In Eastern societies, this might still be the group (family, community, work team) linked by networks (van Dijk, 2006, p. 20). 
The Internet, from networked individualism becomes a basis for the development of new networked communities connected intra and inter themselves in nearly all segments of life and work. Social relations are organized in communication and media networks enabled by ICT development, and are increasingly replacing traditional personal relations. Society is increasingly divided into those designing the networks, those participating in them, and those excluded from them. Hence follows the social and economic differentiation which replaces traditional socioeconomic forms of social divisions. At the same time, there occurs a political decentralization and the transformation of nation states' sovereignty which, in a global context loses its traditional meaning (cf. Castells, 1996, 2000a; Borja, Castells, 1997; Čaldarović Jaeger, 2007; Stiglitz, 2004; Maldini, 2013b).

The globalization of media strongly fosters horizontal forms of communication compared with traditional, mostly vertical forms within nation states. Besides technological changes which were the prerequisites for the new forms of communication, changes are also brought by new organizational, proprietary, and legal forms, thus creating a new information order of global proportions. In this new constellation, unequal access to information results in new inequalities in political and economic power relationships (Giddens, 2006, pp. 582-681).

The asymmetric information distribution due to unequal access, determined primarily by technological requirements, is an important source of inequality. It is manifested first between individuals and social groups within a society, and later between societies themselves. Dualism becomes more pronounced in the social, professional, and economic structure within individual societies, and between societies on a global level (Castells, 1996; Čaldarović Jaeger, 2007). Although economic development is a requirement for ICT development, the latter is increasingly becoming a key social resource. Thus undeveloped societies, where Internet access is limited or absent - and, by extension, access to information and services it provides - are further hampered in their development. They cannot follow the rapid changes caused by ICT development, which additionally widens the gap between the developed and the undeveloped, the online and the offline, the computer literates and the illiterates. All of this inhibits the development of political participation and democracy, so those societies regress not only economically, but also politically.

Even in developed societies, however, where the majority of citizens have Internet access, 
a gap between the abilities of new (Internet, digital) media and their power to improve democracy can be noticed. Their democratic potential, i.e. the power that the citizens could objectively have by using their abilities, is limited, since they are largely controlled, directed, and subjected to the interests of private and state organizations. New media, especially the ubiquitous social networks, are for the most part owned by large and powerful companies which are primarily profit-oriented. A question arises here about their social responsibility with regard to processing and systematic use of information for their own or their clients' benefit. Namely, tracking their huge number of users provides them with insight into their behavior, attitudes, and preferences, thus also letting them influence the public opinion and direct social, and consequently political trends (by emphasizing or ignoring certain content, which influences the behavior of large social groups). The power afforded by such a position is disproportionately greater than the power and influence it provides to its users. Since these companies are mostly multinational corporations with a monopolistic position acting in a free and deregulated global market, there is no possibility for their (democratic) control.

In the constellation dominated by large and powerful organizations, most individual and group voices are lost. Added to this should be the unavoidable Internet giants, which set not only the standards of communication, but also influence the content being communicated. Agenda setting still remains in the hands of the most powerful. Their domination has been largely brought over or even intensified by the use of new media, while citizens' participation, although much greater and more diversified, has remained in the background.

Although in principle a greater degree of use of social networks enables greater political participation, a greater number of users also mean greater profits (due to a larger number of advertisers and business clients), and consequently greater power. Therefrom occurs a paradox - greater participation of citizens in social networks leads to greater control over the citizens. Although not political by itself, this control still potentially limits the user's freedom and influence on political processes. ${ }^{11}$

11 A drastic example is Google's cooperation with the autocratic regime of PR China in 2006, when it agreed, in the interest of profit (based on a huge number of users), to limit access and allowed the government to censor and filter Internet traffic, which included almost all social networks. 


\section{Social networks: Possibilities and limitations of political participation through virtual socialization}

Development of social networks, besides significantly changing forms and channels of communication, also influences the transformation of the existing and the forming of new social structures. Traditional forms of socialization give way to new, virtual forms, especially social networks. On one hand, these new forms of socialization far surpass the traditional social structures with their reach and abilities. On the other hand, they are substantially limited.

Networks, as groups of individuals or social groups connected by a certain common interest (economic, political, cultural), were always a part of the social structure. ${ }^{12}$ They were not, however, so numerous or dominant as they are now. For example, in the industrial society, marked by social classes as dominant socio-economic groups, citizens' connecting into networks had an important function, although secondary in terms of influence on social dynamics. Traditional social classes, as dominant subjects of social structure, and the social and political (ideological) cleavages were the direct product of the technology of industrial production. However, with the emergence of ICT and the Internet as a global network that equally accelerated economic, political, and cultural flows, networking becomes a new mode of sociality and creating bonds, and influences the dissolution of traditional social structures and the formation of new ones. They become a global communication phenomenon and encompass countless groups of autonomous individuals gathered in mostly informal groups (Castells, 2000b).

Unlike past social networks, the Internet-based ones have two very different and new features. They are not limited in the spatial sense, not necessarily local (territorial) as they used to be, but instead are global (Borja, Castells, 1997). The term "glocal", which in a specific way connects global and local, is perhaps the best description for this new characteristic. ${ }^{13}$ In addition, new social networks are above classes and nations since they gather members of

12 In the early 20th century, Simmel Georg (1971) has shown that society is based on interaction between individuals, and that the forms of interaction are a key influence on the constitution and the integration of social life. Connections formed within economic, political, social forms of social life provide a sense of unity, thus forming social structures. Social networks (as relationship networks), in this context, have a greater significance than individual social groups (Simmel, 1971, pp. 12-13; 23-25).

13 Glocalization is meant as a process of the mingling of global and local, where the boundaries between them are blurring. It means that trends of homogenization and heterogenization coexist throughout the modern age, and that local culture assigns meaning to global influences. Therefore, they are interdependent and enable each other (Robertson, 1995). 
different social groups and different societies (countries) around shared interests. In that sense, new social structures generated around social networks represent novelty, different from all prior social structures. Likewise, forms of political participation are transformed from the traditional ones, characteristic for civil society (within the borders of a nation state), to a completely other level, much wider and with potentially greater possibilities (transnational, cosmopolitan, or global civil society) (Giddens, 1990, pp. 55-78; Held, 1998, pp. 12-13, 24-25).

New social networks develop on their own and in the extremely dynamic environment of the new technologies. The Internet, as the network of all networks, is a source and a place for exchange of almost every possible piece of information, but is also the place of mutual interaction between almost all other social, political, and economic actors, which connect and network themselves in various ways and with various interests in mind. Their digital language signifies their real needs and goals, making cyberspace merely an extension of real life, or rather a new dimension of real life.

In that context, social networks are just one, although relevant, segment of connectedness and socialization which influences the formation of new social structures, from volatile and informal ones to strong and very influential ones. Since they are public, and thus a part of public discourse, social networks enable a direct and public response to political processes in society, which opens up the possibility of political influence, i.e. political participation.

In addition, social networks elude censorship and government control, so they are often the only channel (especially in undemocratic, closed, repressive regimes) individuals and groups have for freely expressing their political attitudes and criticizing the government. Similarly, they are often the only communication channel from politically and economically independent media to the public, and the only way they can reach a wide audience. All this opens up possibilities which were until recently unimaginable, for individuals' and social groups' political influence on the government and on the formation of public opinion.

However, social networks, new media, and the entire cyberspace, despite their communication, socialization and participation capabilities which surpass all prior ones, are still merely an extension of the existing real world, and do not have a separate existence. All these forms of virtual socialization and new forms of communication stem from real life and are its integral part, regardless of being in a separate space and using specific communication channels. Values, 
symbols, and semantics of real life are transposed into the virtual sphere. Transposition, however, does not imply transformation, so origins, content, and perception of certain values, ideas, information, and symbols remain largely unchanged. They are determined primarily by sociocultural factors such as historical and political legacy, political culture, and dominant values of a particular society. Those are endogenous factors, specific for each society, which as a sociocultural context substantially affect the functioning of the political system, including the scope and quality of political participation.

With this in mind, it is possible to understand and explain the relatively modest achievements in the development of political participation and democracy in general, in societies in which the sociocultural context does not correspond to democratic institutions (recently established, in transitional societies) or in autocracies (where democratic culture is nonexistent). In the latter, for example, mass protests incited by activism on social networks, have failed to achieve their goals - even with external stimulation - primarily due to a lack of deeply rooted democratic values in the wider population. ${ }^{14}$ This is precisely the problem of northAfrican and middle-Eastern societies, where revolutions have helped to articulate mass dissatisfaction and mobilize citizens to overthrow autocratic regimes, but not to set up and consolidate democracy. ${ }^{15}$ Indeed, those countries have experienced retrograde processes marked by political conflicts with pre-civil characteristics.

On the other hand, in transitional and post-transitional societies - despite a relatively high level of ICT development and rather high Internet accessibility - the content (topics, rhetoric, narratives, and style) of information mediated by social networks, and the actions of social actors behind them are greatly marked by authoritarian historical and political legacy and patterns of subject, even parochial culture, and only rarely participative civic culture (Almond, Verba, 2000; Maldini, 2011, pp. 270-362). Participative possibilities of the virtual sphere are thus used not necessarily for pro-democratic activity, but often for the opposite.

14 This is about political culture and political structure relationship. Quite simplified, it can be explained so that if political culture does not support political structure (democracy), chances of system's democratic functioning (even for its sustainability) are poor. Culture that consist democratic values widespread and internalized among the majority of citizens (actually, the civic culture) is the type that supports democratic political system and foster democratic processes (Putnam, 2003; Maldini, 2011).

15 During the so-called Facebook and Twitter revolutions, social networks and new media were assigned an almost supernatural role. However, they were shown to be merely a medium which reflected the real state of the society: revolt due to dissatisfaction, but not a solution or a vision of social and political development. Finally, it is evident that the voiced opinions belonged mostly to a loud minority, and were not widespread, majority opinions. As a result, ideas promoted in cyber space haven't become widely accepted; they weren't a part of the prevailing opinions and attitudes. They were sufficient for the deconstruction of the existing autocratic regime, but not for a construction of a new (democratic) one. 
That sociocultural phenomenon - as an originally endogenous factor characteristic for each particular society - is one of the greatest obstacles not only to efficient political participation, but also to faster democratization of many transitional societies. Those societies, on their path of democratization, have stopped halfway there, often ending up in some new form of authoritarianism. ${ }^{16}$

Finally, it needs to be said that the experience of developed democracies has shown that social activism requires relatively strong connections between citizens, which is not a characteristic of virtual networks, where connections are random, volatile, often shallow and impermanent. Despite their huge advantages in the numbers they can gather, speed of information exchange, and space covered, social networks (and other forms of virtual socialization) still do not have the cohesive power that traditional face-to-face forms of socialization do. Social networks are a great way for keeping in touch, disseminating information, and short-term activity. Civil activism, on the other hand, requires an organizational structure and strong connections between social actors and a significantly higher level of personal involvement, motivation, and exposure. All this is not the case in social networks, where declarative affiliation is usually sufficient, with retaining anonymity, or with a minimum of personal exposure. Thus political participation on social networks, despite its advantages, often remains limited in its reach, even in societies with a developed democracy and civic culture.

\section{Conclusion}

From all of the foregoing, it is evident that political participation is key for vitality and success of modern democracies. Citizens' freedom and ability to influence political processes (especially political decision-making), legitimacy of the government, and the representativeness of the political system, depend on its level. The level of participation is therefore one of the essential measures for the level of democratization. A developed civil society is a sociostructural prerequisite of the public sphere where the public political discourse - essential for articulation of democratic politics - takes place. A developed civic culture, in turn, is an essential sociocultural

16 These facts warn that transition is not an unambiguous and predictable process which inevitably leads to democracy. Many formally democratic regimes, which satisfy some or most requirements of a minimal democracy, are actually quasi-democratic regimes, where behind a democratic facade the government obstructs the opposition, prevents political participation, public control, and civil freedoms. Such regimes are called "democraduras" (O’Donnell, Schmitter 1986, p. 41), illiberal, or "defective democracies" (Merkel, 2004). 
prerequisite of substantive democracy. Without those prerequisites, political participation, as a key characteristic of developed democracy, is not possible. Mass media are mediators of public opinions inasmuch as they are political actors in creating it. They are therefore a key instrument in forming the public political discourse and directing citizens' and social groups' participation in politics. Their function is therefore equally communicational (source of information, communication channel) and political (mediation, inclusion, agenda setting).

ICT development has brought new media and new forms of communications, which has substantially changed the entire communication paradigm. Key changes it brought are interaction (two-way communication), unity of time and space, decentralization, and deterritorialization. In addition, development of new media and the connections between numerous individuals and social groups have made the cyberspace a virtual space for not just simple communication, but all other elements of social life as well. In this context, the public sphere is transformed, and forms of public and political activity with it. Simultaneously, social networks, as new forms of virtual socialization, significantly influence the transformation of traditional social structures and create the structure of a new, network society. All this significantly expands the area of political actors' activity with regard to communication, which opens up new and greater possibilities for political participation.

However, it is evident from the preceding analysis that new forms and channels of public communication created by ICT, as well as new horizontal networks of social bonds and the forms of virtual socialization, do not, per se, increase the level of political participation nor citizens' influence on political decision-making. In addition to technological limitations (primarily accessibility, which is the basic precondition for inclusion or exclusion), the crisis of democracy, both in established democracies and in post-transitional societies, and the failure to establish democracy in authoritarian societies, suggest that - despite the many opportunities that ICT brought - political participation essentially depends on the sociostructural and sociocultural factors, as intrinsic properties of certain societies that substantially determine their overall social and political dynamics.

New virtual communities are not isolated from the societies they originated from. Similarly, the dominant values and political culture of these communities stem from their members, socialized in a real social context. Hence, it follows that new media and social networks are merely a new instrument, but not necessarily new content nor new awareness. They open up 
new spaces and provide new possibilities, but do not act or solve problems all by themselves. A social network facilitates communication among members, but is not a replacement for protests or other forms of political participation.

It might be concluded that ICT mediated communication and virtual socialization, despite their undoubtedly enormous potential for stimulating political participation and influencing the government and the processes of political decision-making, are still subject to the same limitations as all other segments of democratic development in certain societies. In that sense, the level of development of the virtual sphere, the large numbers and diversity of social networks and new media, cannot by themselves be considered independent variables, nor outside the specific social context. Cyberspace has been shown to be a reflection or an extension of the real world, determined by the same factors which shape and form social and political processes in society. In that sense, the objectively greater possibilities for political participation and their potential influence on political decision-making will be stimulated or hampered precisely by these endogenous factors, characteristic for each individual society.

\section{Reference List}

- Almond, G., Verba, S. (2000). Civilna kultura: politički stavovi i demokracija u pet zemalja. Zagreb: Politička kultura.

- Beyme, K. von (1996). Transition to Democracy in Eastern Europe. Hampshire, London: Macmillan Press; New York: St. Martin's Press.

- Böckenförde, E.W. (1991). Značenje razlikovanja države i društva u demokratskoj socijalnoj državi sadašnjosti. In: Pokrovac, Z. (Ed.), Građansko društvo i država: povijest razlike i nove rasprave (pp. 217-231). Zagreb: Naprijed.

- Borja, J., Castells, M. (1997). Local and Global: The Management of Cities in the Information Age. London: Earthscan.

- Castells, M. (1996). The Rise of the Network Society. Oxford: Blackwell Publishers.

- Castells, M. (2000a). Toward a Sociology of the Network Society. Contemporary Sociology, 29 (5), 693-699.

- Castells, M. (2000b). Materials for an exploratory theory of the network society. British Journal of Sociology, 51 (1), 5-24.

- Crouch, C. (2004). Post-Democracy. Cambridge: Polity Press.

- Čaldarović Jaeger, Lj. (2007). Informacijski umreženo društvo - društvo krajnjih nejednakosti?. Društvena istraživanja, 16 (3), 405-429.

- Dalton, R. J. (2006). Citizen Politics: Public Opinion and Political Parties in Advanced Industrial Democracies. Washington, D.C: CQ Press.

- Davis, R. (2005). Politics Online: Blogs, Chatrooms, and Discussion Groups in American Democracy. New York: Routledge.

- van Dijk, J. (2006). The Network Society. Social Aspects of New Media. London, Thousand Oaks, New Delhi: Sage Publications.

- Edelman, M. (2003). Konstrukcija političkog spektakla. Zagreb: Politička kultura.

- Fukuyama, F. (1989). The End of History?, The National Interest, 16, 3-18.

- Giddens, A. (1990). The Consequences of Modernity. Cambridge: Polity Press.

- Giddens, A. (2006). Sociology. Cambridge: Polity Press.

- Graber, D. (2003). The Media and Democracy: Beyond Myths and Stereotypes. Annual Review of Political Science, 6, $139-160$. 
- Grugel, J. (2002). Democratization: A Critical Introduction. New York: Palgrave Macmillan.

- Habermas, J. (1991). The Structural Transformation of the Public Sphere: An Inquiry Into a Category of Burgeois Society. Cambridge, MA: MIT Press.

- Held, D. (1998). Democracy and Globalization. In: Archibugi, D., Held, D., Köhler, M. (Eds.), Re-Imagining Political Community: Studies in Cosmopolitan Democracy (pp. 11-27). Stanford: Stanford University Press.

- Huntington, S. (1991). The Third Wave. Democratization in the Late Twentieth Century. Norman, London: University of Oklahoma Press.

- Inglehart, R., Welzel, C., Klingemann, H. D. (2003). The Theory of Human Development. European Journal of Political Research, 42 (2), 341-80.

- Kaldor, M., Vejvoda, I. (1997). Democratization in Central and East European Countries. International Affairs, 73 (1), 59 -82.

- Maldini, P. (2002). Građansko društvo i demokracija u tranzicijskim društvima. Politička misao, 39 (4), 129-145.

- Maldini, P. (2008). Demokracija i demokratizacija. Dubrovnik: Sveučilište u Dubrovniku.

- Maldini, P. (2011). Politička kultura i demokratska tranzicija u Hrvatskoj. Dubrovnik: Sveučilište u Dubrovniku.

- Maldini, P. (2013a). Postkomunizam i postdemokracija: kriza demokracije i mjerila demokratičnosti. In: Milardović, A., Jožanc, N. (Eds.), Demokracija i postdemokracija (pp. 209-239). Zagreb: Pan liber, Institut za europske i globalizacijske studije.

- Maldini, P. (2013b). The Nation-State and Global Surroundings: The Issue of Sovereignty. Studia Politica Slovaca, 6 (2), 5-23.

- McLuhan, M. (1962). The Gutenberg Galaxy: The Making of Typographic Man. Toronto, Buffalo, London: University of Toronto Press.

- McLuhan, M., Fiore, Q. (1968). War and Peace in the Global Village. New York: Bantam Books.

- McNair, B. (2003). Uvod u političku komunikaciju. Zagreb: Fakultet političkih znanosti Sveučilišta u Zagrebu.

- Merkel, W. (2004). Embedded and Defective Democracies. Democratization, 11 (5), 33-58.

- Meyer, T. (2003). Mediokracija - Medijska kolonizacija politike. Zagreb: Fakultet političkih znanosti.

- Norris, P. (2001). Digital Divide: Civic Engagement, Information Poverty, and the Internet Worldwide. New York: Cambridge University Press.

- O’Donnell, G., Schmitter, P. (1986). Transition from Authoritarian Rule: Tenative Conclusion about Uncertain Democracies. Baltimore: The Johns Hopkins University Press.

- Offe, C. (1997). Cultural Aspects of Consolidation: A Note on the Peculiarities of Postcommunist Transformations. East European Constitutional Review, 6 (4), 64-68.

- Posavec, Z. (2004). Javnost i demokracija. Politička misao, 41 (1), 5-10.

- Putnam, R. (2003). Kako demokraciju učiniti djelotvornom: Civilne tradicije u modernoj Italiji.Zagreb: Fakultet političkih znanosti Sveučilišta u Zagrebu.

- Ranciere, J. (2008). Mržnja demokracije. Zagreb: Naklada Ljevak.

- Robertson, R. (1992). Globalization: Social Theory and Global Culture. London: Sage Publications.

- Robertson, R. (1995). Glocalization: Time-space and Homogeneity- heterogeneity. In: Featherstone, M., Lash, S., Robertson, R. (Eds.), Global Modernities (pp. 25-44). London: Sage Publications.

- Simmel, G. (1971). On Individuality and Social Forms. Chicago: University of Chicago.

- Stiglitz, J. (2004). Globalizacija i dvojbe koje izaziva. Zagreb: Algoritam.

- Thompson, J. B. (1995). The Media and Modernity: A Social Theory of the Media. Cambridge: Polity Press; Stanford: Stanford University Press.

- Tilly, C. (1999). Processes and Mechanisms of Democratization. Sociological Theory, 18 (1), 1-16.

- Vujčić, V. (1999). Politička kultura i politička struktura: odnos političke kulture, strukture i demokracije (I. dio). Politička misao, 36 (1), 113-139.

- Wolin, S. (2008). Democracy Incorporated: Managed Democracy and the Specter of Inverted Totalitarianism. Princeton: Princeton University Press. 


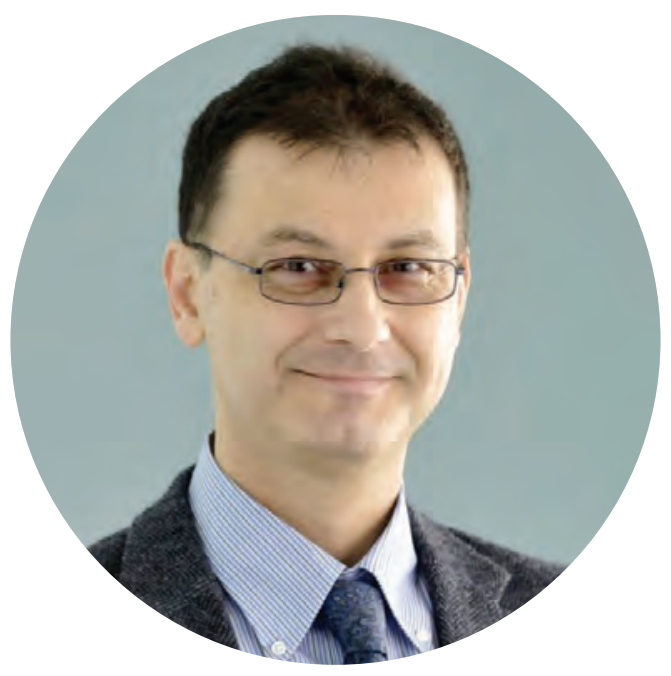

\section{Pero Maldini}

Pero Maldini, $\mathrm{PhD}$, is an associate professor at the Department of Communication Science at University of Dubrovnik, Head of Interdisciplinary Doctoral Study of Communication Science at University of Osijek and Head of Department of Intercultural Communication at Edward Bernays College for Communication Management in Zagreb. He has published four books and a number of papers in the field of comparative politics, democratic theory, political culture, media and politics, political education, and presented his works at more than 20 international conferences. He has received several international grants for research training abroad in the USA, the Netherlands, Hungary and Slovakia. He is a member of the Executive Board of the Croatian Political Science Association and a member of three journal editorial boards. 